\title{
Suspected COVID-19 flu-like syndrome in men who have sex with men and have been involved in casual sex
}

\author{
Síndrome gripal suspeita de COVID-19 em homens que fazem sexo com homens e se envolveram em sexo casual
}

Síndrome gripal sospech a de COVID-19 en hombres que tienen sexo con hombres y se envolvieron en sexo ocasional

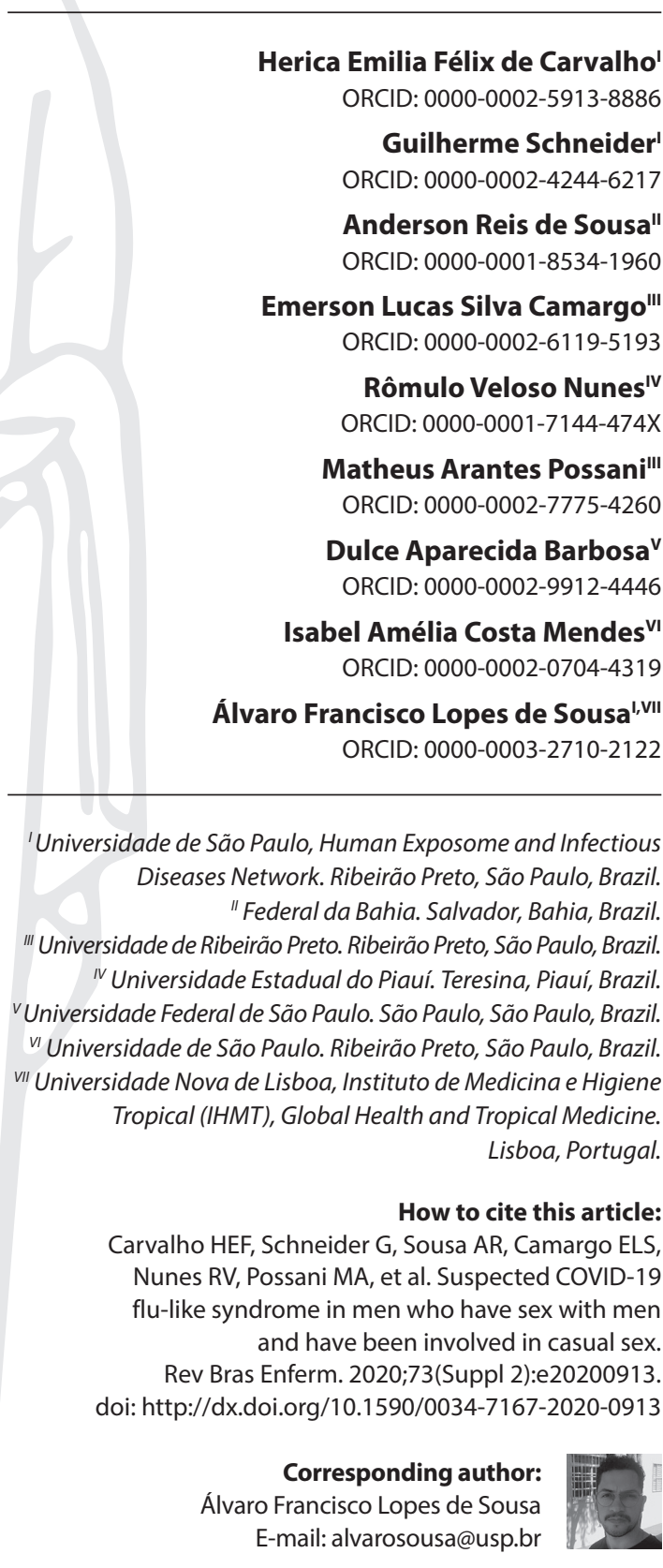

EDITOR IN CHIEF: ANTONIO José De Almeida Filho ASSOCIATE EDITOR: Elucir Gir

\begin{abstract}
Objective: To evaluate the presence of flu-like syndrome suggestive of COVID-19 in men who have sex with men (MSM) and engaged in casual sex during a period of social isolation. Method: National epidemiological survey, applied in April and May 2020, by adaptation of Respondent Drive Sampling. Results: 1,337 MSM participated in the survey, of which 514 (38.4\%) had fever associated with another sign or symptom of flu-like syndrome. Social, demographic characteristics, sexual practices and activities during the period of social isolation were statistically associated with the presence of flu-like syndrome. There was a statistical difference $(p<0.001)$ in the average of partners between those who had signs and symptoms of flu-like syndrome (3.5) and those who did not (1.7). Conclusion: Evidence of signs and symptoms indicative of flu-like syndrome suggestive of COVID 19 in Brazilian MSM who were involved in casual sex during the period of social isolation. Descriptors: Men; Homosexuality, Male; Coronavirus; Pandemics; COVID-19.
\end{abstract}

\section{RESUMO}

Objetivo: Avaliar a presença de síndrome gripal suspeita de COVID-19 em homens que fazem sexo com homens (HSH) e se envolveram em sexo com parceiro casual durante período de distanciamento social. Método: Inquérito epidemiológico, de abrangência nacional, aplicado em abril e maio de 2020, por adaptação do Respondent Drive Sampling. Resultados: 1.337 HSHs participaram da pesquisa, dos quais $514(38,4 \%)$ tiveram febre associada a outro sinal ou sintoma de síndrome gripal. Características sociais, demográficas, práticas e atividades sexuais durante o período de distanciamento social foram estaticamente associadas à presença de síndrome gripal. Houve diferença estatística $(p<0,001)$ na média de parceiros entre aqueles que tiveram sinais e sintomas de síndrome gripal $(3,5)$ e aqueles que não os tiveram $(1,7)$. Conclusão: Evidencia-se ocorrência de sinais e sintomas indicativos de síndrome gripal sugestiva de COVID19 em HSHs brasileiros que se envolveram em sexo casual durante o período do distanciamento social.

Descritores: Homens; Homossexualidade Masculina; Coronavírus; Pandemia; COVID-19.

\section{RESUMEN}

Objetivo: Evaluar la presencia de síndrome gripal sospecha de COVID-19 en hombres que tienen sexo con hombres (HSH) y se envolvieron en sexo con pareja ocasional durante distanciamiento social. Método: Averiguación epidemiológica, de abarcamiento nacional, aplicado en abril y mayo de 2020, por adaptación del Respondent Drive Sampling. Resultados: 1.337 HSHs participaron de la investigación, de los cuales 514 (38,4\%) tuvieron fiebre relacionada a otra señal o síntoma de síndrome gripal. Características sociales, demográficas, prácticas y actividades sexuales durante el distanciamiento social han estáticamente relacionadas a la presencia de síndrome gripal. Hubo diferencia estadística $(p<0,001)$ en la media de parejas entre aquellos que tuvieron señales y síntomas de síndrome gripal $(3,5)$ y aquellos que no los tuvieron $(1,7)$. Conclusión: Se evidencia ocurrencia de señales y síntomas indicativos de síndrome gripal sugestivo de COVID-19 en HSHs brasileños que se envolvieron en sexo ocasional durante el período del distanciamiento social.

Descriptores: Hombres; Homosexualidad Masculina; Coronavirus; Pandemia; COVID-19. 


\section{INTRODUCTION}

At the end of December 2019, the world became aware of the existence of the new coronavirus, SARS-CoV-2 - Severe Acute Respiratory Syndrome Coronavirus 2, the virus that caused the COVID-19 pandemi ${ }^{(1)}$.Eight months later, the disease has killed more than 865,000 people around the world, 124,000 of them in Brazil alone, by the end of August ${ }^{(2)}$. As there are not enough inputs for diagnostic case testing in the country, which has one of the lowest test rates in the world, health agencies are required to make case definitions (suspect/confirmed/ disposed) less accurate ${ }^{(3-4)}$.

In general, in Brazil, the definition of a suspected case of COVID-19 can be based on signs and symptoms of flu-like syndrome (FS) and severe acute respiratory syndrome (SARS), with three possibilities of confirmation, according to the Brazilian Ministry of Health ${ }^{(5)}$ : 1. By clinical-epidemiological criteria: case of FS or SARS with clinical confirmation associated with anosmia or acute aging; 2 . By clinical-epidemiological criteria: case of FS or SARS with a history of close contact or in an area of sustained transmission (community), in the 14 days before the appearance of signs and symptoms with a confirmed case for COVID-19; 3. By clinical-imaging criteria: case of FS or SARS or death from SARS that could not be confirmed by laboratory criteria and that presents suggestive tomographic alterations.

Because it is considered, until then, the greatest health challenge of the 21st century, due to the high rates of transmissibility and the deficient capacity of mitigation and mass testing, social isolation is being pointed out as the most recommended and adopted mitigation measure to reduce the probability of the infectious agent transmitting among the population, thus delaying the quantity of those infected by the disease ${ }^{(6)}$. However, its adhesion has oscillated negatively, especially in Brazil( ${ }^{(7)}$.

A possible explanation for this can be found in the finding that social isolation has generated impacts on the physical, psychological and sexual health of individuals ${ }^{(8-9)}$. However, such repercussions are felt disproportionately according to population groups, and in the case of vulnerable people such as the group of men who have sex with men (MSM), who are historically marginalized and have their sexual practices rejected and socially limited to invisible/unseen places, the need for peer and similar social support may be more important and necessary ${ }^{(10-11)}$, this is why failure to adhere completely to social isolation measures should be studied and better elucidated.

Little is known about the real role and impact of sexual relations with casual partners in the current pandemic situation of COVID-19. Studies ${ }^{(11-12)}$ show that the continuous state of partial detachment can make people more likely to neglect isolation in pursuit of interaction or sexual pleasure. In this regard, a multicenter study conducted in Portugal and Brazil in 2020 showed that $53 \%$ of MSM have difficulty complying with social isolation measures, participate in sex meetings without condoms $(30.4 \%)$, with multiple partners (15.8\%), and under drug use (Chemsex) (39\%) ${ }^{(12)}$.

Casual sexual relations with one or multiple partners can be an important route of contamination and transmission of the viruses that cause COVID-19 $9^{(12-13)}$, since they involve the meeting of two or more people for a considerable time in an enclosed space. In order to raise associations, not yet tested in the literature, between potential sexual exposure to SARS CoV-2 through casual sex and the development of signs and symptoms of flu-like syndrome suggestive of COVID-19, we developed this study.

\section{OBJECTIVE}

To evaluate the presence of flu-like syndrome suggestive of COVID-19 in men who have sex with men (MSM) and engaged in casual sex during a period of social isolation.

\section{METHODS}

\section{Ethical aspects}

This is a subproject of the multi-centric research"In_PrEP Brazil/ Portugal", originally approved by the Research Ethics Committee of the New University of Lisbon and the Ribeirão Preto School of Nursing in 2019. Due to the addition of questions, an amendment was presented and approved.

\section{Design, time and place of study}

The sub-project "40TENA" was a multi-center online epidemiological survey applied in all 26 Brazilian states. The research project and the presentation of this manuscript were guided by the STROBE tool and The Checklist for Reporting Results of Internet E-Surveys (CHERRIES) ${ }^{(14)}$. There was a dynamic data collection in April and May 2020 while the Brazilian states were experiencing restrictive sanitary measures that requested social isolation and distancing, in addition to quarantine to prevent the spread of the virus.

\section{Population or sample}

The sample consisted of 2,646 participants recruited by adapting the Respondent Drive Sampling (RDS) method to the virtual environment. In this method, the participant him/ herself is responsible for recruiting other individuals of the same category as his/her, using his/her social networks. To meet the method's requirements, we selected 15 MSM with different characteristics regarding: location in the country (divided according to the five regions); race/color: white and not white; age: young, adult and elderly; and level of education. These were the first participants and were called seeds. 1,407 MSM were eligible to participate in the study because they had sex with a casual partner. Of these, 70 were excluded because they had already been tested for COVID-19, and the final sample was fixed at 1,337 participants (Figure 1).

\section{Study protocol}

Each participant received the link of the survey and was guided to invite more MSM from their social network until a significant sample was obtained. The seeds were identified through two geolocation-based meeting applications (Grindr and Hornet), by direct chat with online users. 


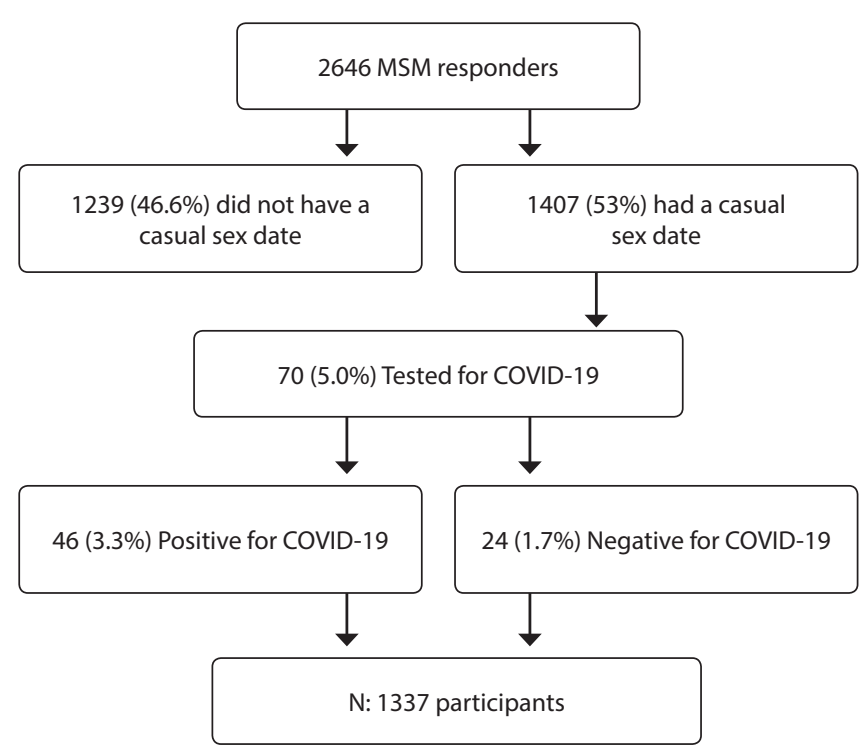

Figure 1 - Participant selection flowchart

The researchers also used the Facebook social network drive, targeting the population of MSM aged 18 to 60 (age limit imposed by Facebook), through a fixed post on the official survey page (https://www.facebook.com/taafimdeque/) and accompanied by an electronic link, which provided access to the Free and Informed Consent Term and the survey questionnaire. We included only individuals who identified themselves as male, cisgender or transgender, 18 years of age or older and resident in Brazil.

The instrument used for data collection was prepared by the researchers, who considered the variables of interest for the research and characterization of the participants, and validated as to form and content by a group of experts in the theme and method. It was divided into sections ranging from socio-demographic information to issues of behavior and sexual practices common in times of non-pandemic as well as in the period of distance, social isolation and/or quarantine.

The data collection form was hosted on a website and only allowed one response per IP (internet protocol), for security reasons. It was divided into sections ranging from socio-demographic information to mental health, sexual and sexuality issues in the period of estrangement, social isolation and or quarantine.

\section{Analysis of results and statistics}

In the context of COVID-19, according to the orientation of the Brazilian Ministry of Health ${ }^{(5)}$, diagnosis should be suspected in patients with fever and/or signs/symptoms of low influenza disease, e.g.: cough and dyspnea, who reside or have been in territory with sustained/community transmission of COVID-19. Following these recommendations, we define a "suspected case of flu-like syndrome" as an individual with acute respiratory symptoms, characterized by a fever or febrile sensation, even if reported, accompanied by cough OR sore throat OR runny nose OR breathing difficulty.

We defined "sex with a casual partner" or simply "casual sex" as a face-to-face sexual activity (oral or penetrative sex) with a new or unknown partner who was outside the place where he or she was staying. Thus, the direct question was asked: "Since the social isolation/looseness was proposed in Brazil, have you had sex with a new or unknown partner who is outside the place where you are sheltered, or have you moved to find this partner?".

The data was analyzed with the help of the Statistical Package for the Social Sciences (SPSS) for Windows, version 22.0. Descriptive and univariate analyses were performed. The normality of the data was evaluated by the Shapiro-Wilk test, applied to the numerical variables. In the case of categorical variables, the associations were tested using Fisher's exact chi-square test, and the significance level was set at $\leq 0.05$, with a $95 \%$ confidence interval. In this statistical model, it was adopted as a binary outcome (yes or no) the suspicion of flu-like syndrome, that is, any individual who presented fever or feverish sensation accompanied by any of the signs and symptoms investigated, namely: tiredness or fatigue; dyspnea or respiratory discomfort; sore throat and cough.

The Student t-test was used to compare means between individuals classified as a suspect case (yes) and those who were not classified as a suspect case of RS.

\section{RESULTS}

There were 1,337 Brazilian MSM who had casual sex during the COVID-19 pandemic. The predominant age group was 21 to 30 years old $(69.5 \%)$, living in metropolitan regions (75.2\%), single (72.2\%). The majority (96.3\%) reported that they had been practicing some kind of social distancing (social isolation; social distancing/Staying at home or quarantine) for more than 30 days (74.9\%), with a perception of a high impact of social isolation on their daily activities (44.3\%).

By means of bivariate statistics, we tested the association between the characteristics of the sample and the presence of signs and symptoms of flu-like syndrome. The following were statistically associated: Age, Living in a metropolitan area, Duration of social isolation, Perceived impact of social isolation, Sexual practices (Type of partner; Type of relationship; and Living with the sexual partner); and Sexual activity during the period of social isolation (Search for paid sex; Sexual relationship, simultaneously, with two or more partners; Sexual relationship under the effect of licit or illicit substances; Sexual relationship without protection, whether active and/or passive).

Table 3 highlights the comparison of mean age and number of sexual partners during the period of social isolation from the COVID-19 pandemic, with the presence of flu-like syndrome signs and symptoms, and shows that there was a statistical difference $(p<$ 0.001 ) in the mean number of partners between those who had flulike syndrome signs and symptoms (3.5) and those who did not (1.7).

Table 1 - Social and demographic characterization of sexual practices and signs and symptoms of flu-like syndrome in men who have sex with men and had casual sex during a period of social isolation from the COVID-19 pandemic, Brazil, $2020(\mathrm{~N}=1,337)$

\begin{tabular}{lcc}
\hline Variables & $\mathbf{n}$ & $\%$ \\
\hline $\begin{array}{l}\text { Social and demographic characterization } \\
\text { Gender identity } \\
\quad \text { Cisgender man }\end{array}$ & & \\
$\quad$ Transgender man & 1.333 & 99.7 \\
\hline & 4 & 0.3 \\
\hline
\end{tabular}




\begin{tabular}{lcc} 
Table 1 (concluded) & & \\
\hline Variables & $\mathbf{n}$ & $\%$ \\
\hline $\begin{array}{l}\text { Dyspnea/Respiratory discomfort } \\
\quad \text { Yes }\end{array}$ & 479 & 35.8 \\
$\quad$ No & 858 & 64.2 \\
At least one sign/symptom & & \\
$\quad$ Yes & 790 & 59.1 \\
$\quad$ No & 547 & 40.9 \\
Fever associated with another sign/symptom of flu-like & & \\
Syndrome & & \\
$\quad$ Yes & 514 & 38.4 \\
$\quad$ No & 823 & 61.6
\end{tabular}

\begin{tabular}{|c|c|c|}
\hline Variables & $\mathbf{n}$ & $\%$ \\
\hline \multicolumn{3}{|l|}{ Age } \\
\hline $18-20$ years & 68 & 5.1 \\
\hline $21-30$ years & 930 & 69.5 \\
\hline $31-40$ years & 172 & 12.9 \\
\hline $41-50$ years & 111 & 8.3 \\
\hline$>50$ years & 56 & 4.2 \\
\hline \multicolumn{3}{|c|}{ Resides in metropolitan area/large centers? } \\
\hline Yes & 1005 & 75.2 \\
\hline No & 332 & 24.8 \\
\hline \multicolumn{3}{|l|}{ Current relationship type } \\
\hline Single & 965 & 72.2 \\
\hline In a polyamorous relationship & 48 & 3.6 \\
\hline In a fixed relationship & 324 & 24.2 \\
\hline \multicolumn{3}{|l|}{ Who do you usually have sex with? } \\
\hline Casual partner & 971 & 72.6 \\
\hline Casual/fixed partners & 215 & 16.1 \\
\hline Fixed partner & 151 & 11.3 \\
\hline \multicolumn{3}{|c|}{ Are you living with your sexual partner? } \\
\hline Yes & 156 & 42.7 \\
\hline No & 209 & 57.3 \\
\hline \multicolumn{3}{|l|}{ Are you in social isolation? } \\
\hline Yes & 850 & 63.6 \\
\hline Partially & 438 & 32.7 \\
\hline No & 49 & 3.7 \\
\hline \multicolumn{3}{|c|}{ Duration of the current social isolation } \\
\hline Less than 30 days & 294 & 22 \\
\hline Between 30 and 45 days & 765 & 57.2 \\
\hline More than 45 days & 237 & 17.7 \\
\hline I am not in social distancing & 41 & 3.1 \\
\hline \multicolumn{3}{|c|}{$\begin{array}{l}\text { How do you rate the impact of social isolation } \\
\text { in your life? }\end{array}$} \\
\hline High impact & 593 & 44.3 \\
\hline Medium impact & 561 & 42 \\
\hline Low impact & 183 & 13.7 \\
\hline
\end{tabular}

Table 2 - Bivariate analysis of factors associated with the presence of signs and symptoms of flu-like syndrome in men who have sex with men and had casual sex during the period of social isolation by the COVID-19 pandemic Brazil, $2020(n=1,337)$

Partnerships and sexual activities during periods of social isolation

Number of partners

1

2 to 3

$>3$

$456 \quad 34.1$

$762 \quad 57$

$119 \quad 8.9$

Paid for sexual relations

Yes

$\begin{array}{ll}59 & 4.4\end{array}$

No

$1.278 \quad 95.6$

Orgy/Menage (Sexual intercourse, simultaneously, with two or more people)

Yes

$385 \quad 28.8$

No

$952 \quad 71.2$

Chemsex (Sexual intercourse under the effect of licit or illicit substances)

Yes

No

Sexual intercourse without condom use?

Yes

$395 \quad 29.5$

$533 \quad 39.9$

No

$804 \quad 60.1$

Signs and symptoms of flu-like syndrome presented in the period of social isolation

\begin{tabular}{lcc} 
Fever & & \\
Yes & 516 & 38.6 \\
No & 821 & 61.4 \\
Cough & & \\
Yes & 781 & 58.4 \\
No & 556 & 41.6 \\
Sore throat & & \\
$\quad$ Yes & 776 & 58 \\
No & 561 & 42 \\
Tiredness or fatigue & & \\
Yes & 378 & 28.3 \\
No & 959 & 71.7 \\
\hline
\end{tabular}

Presence of signs and symptoms of flu-like syndrome

Factors of interes

$n^{\text {Yes }} \% \quad n^{\text {No }} \%$ p value

Age (years)

18-20

21-30

$31-40$

41-50

More than 50 years

Gender Identity

Cisgender man

Transgender man

Resident in metropolitan area/large centers

Yes

No

Is social distancing

Yes

Partially

No

$\begin{array}{cccc}17 & 25,0 & 51 & 75,0 \\ 392 & 42,2 & 538 & 57,8 \\ 63 & 36,6 & 109 & 63,46 \\ 30 & 27,0 & 81 & 73,03 \\ 12 & 21,4 & 44 & 78,6\end{array}$

$<0,001$

Duration of the current social isolation Less than 30 days

Between 30 and 45 days

More than 45 days

I'm not distancing myself

Perceived impact of social isolation

Low impact

Medium impact

High impact

$\begin{array}{llll}514 & 38,6 & 819 & 61,4\end{array}$

$0,305^{*}$

- $\quad$ - 4100

$<0,001$

$\begin{array}{llll}427 & 42,5 & 578 & 57,5\end{array}$

$87 \quad 25,2 \quad 245 \quad 73,8$

$\begin{array}{llll}330 & 38,8 & 520 & 61,2\end{array}$

$\begin{array}{llll}169 & 38,6 & 269 & 61,4\end{array}$

$\begin{array}{llll}15 & 30,6 & 34 & 69,4\end{array}$

$\begin{array}{llll}104 & 35,4 & 190 & 64,6\end{array}$

$\begin{array}{llll}270 & 35,3 & 495 & 64,7\end{array}$

$\begin{array}{lllll}126 & 53,2 & 111 & 46,8\end{array}$

$\begin{array}{llll}14 & 34,1 & 27 & 65,9\end{array}$

$\begin{array}{llll}89 & 48,6 & 94 & 51,4\end{array}$

$\begin{array}{llll}151 & 26,9 & 410 & 73,1\end{array}$

$\begin{array}{llll}274 & 46,2 & 319 & 53,8\end{array}$

Sexual practices

Type of partner

Casual partner

Casual/fixed partners

Fixed partner

$\begin{array}{llll}427 & 44,0 & 544 & 56,0\end{array}$

$\begin{array}{lllll}69 & 32,1 & 146 & 67,9\end{array}$

$\begin{array}{llll}18 & 11,9 & 133 & 88,1\end{array}$

Current relationship type Single

In a polyamorous relationship In a fixed relationship

$\begin{array}{llll}425 & 44,0 & 540 & 56,0\end{array}$

$\begin{array}{llll}15 & 31,3 & 33 & 68,8\end{array}$

$\begin{array}{llll}74 & 22,8 & 250 & 77,2\end{array}$

Living with your sexual partner Yes

$\begin{array}{llll}26 & 16,7 & 130 & 83,3\end{array}$

0,007 No

$\begin{array}{llll}60 & 28,7 & 149 & 71,3\end{array}$

$0,515^{*}$

$<0,001$

$<0,001$

$<0,001$

$<0,001$

Sexual activity in the period of social isolation due to COVID-19

Paid for sexual relations

$42 \quad 71,2 \quad 17 \quad 28,8<0,001$

Had sex, simultaneously, with two $182 \quad 47,3 \quad 203 \quad 52,7<0,001$

or more people

$395 \quad 41,9 \quad 547 \quad 58,1<0,001$

To be continued 
Table 2 (concluded)

\begin{tabular}{|c|c|c|c|c|c|}
\hline \multirow{3}{*}{ Factors of interest } & \multicolumn{5}{|c|}{$\begin{array}{c}\text { Presence of signs and symptoms } \\
\text { of flu-like syndrome }\end{array}$} \\
\hline & \multicolumn{2}{|c|}{ Yes } & \multicolumn{2}{|c|}{ No } & \multirow{2}{*}{$p$ value } \\
\hline & $\mathbf{n}$ & $\%$ & $\mathbf{n}$ & $\%$ & \\
\hline Had sex without a condom & 297 & 55,7 & 236 & 44,3 & $<0,001$ \\
\hline $\begin{array}{l}\text { Amount of partners during the } \\
\text { period of social withdrawal }\end{array}$ & & & & & $<0,001$ \\
\hline 1 & 67 & 14,7 & 389 & 85,3 & \\
\hline $2-3$ & 343 & 45,0 & 419 & 55,0 & \\
\hline$>3$ & 104 & 87,4 & 15 & 12,6 & \\
\hline
\end{tabular}

Table 3 - Comparison of mean age and number of sexual partners during the period of social isolation from the COVID-19 pandemic, with the presence or absence of signs and symptoms of flu-like syndrome - Brazil, $2020(N=1,337)$

\begin{tabular}{|c|c|c|c|}
\hline \multirow{2}{*}{ Factors of interest } & \multicolumn{3}{|c|}{$\begin{array}{c}\text { Presence of signs and symptoms } \\
\text { of flu-like syndrome }\end{array}$} \\
\hline & $\begin{array}{c}\text { Yes } \\
\text { Average (SD) }\end{array}$ & $\begin{array}{c}\text { No } \\
\text { Average (SD) }\end{array}$ & $\underset{\text { value* }^{*}}{p}$ \\
\hline Ages (years) & $29.92(6.3)$ & $30.54(8.7)$ & 0.165 \\
\hline $\begin{array}{l}\text { Amount of partners during the } \\
\text { period of social isolation }\end{array}$ & $3.5(3.4)$ & $1.7(0.9)$ & $<0.001$ \\
\hline
\end{tabular}

Note: *Test $t$ the Student.

\section{DISCUSSION}

The presence of signs and symptoms of flu-like syndrome suggestive of COVID-19 in men who have sex with men (MSM) and engaged in casual sex during a period of social isolation due to the pandemic in Brazil was significant and associated with social, demographic characteristics, practices and sexual activities over this time. In this sense, this research is pioneering in testing the association between potential exposure to SARSCoV-2 through sex with a casual partner and the development of signs and symptoms of flu-like syndrome characteristic of COVID-19. Although the number of MSM who can be indicated as suspected cases of COVID-19 has been high (38.3\%), we believe that this finding is still considerably undersized because asymptomatic people seem to be responsible for about $40 \%$ to $45 \%$ of SARS-CoV-2 infections(15-16) and may vary substantially according to age group.

As evidenced in our findings, age was associated with the presence of signs and symptoms of COVID-19, reinforcing the impact and influence of age groups in the unfolding of the pandemic. Specifically regarding young people and young adults, the most prevalent group in this study (42.2\%), there are already reports pointing them as drivers of virus-carrying pathogens ${ }^{(17)}$ due to the low adherence to virus containment and mitigation measures and low symptomatology rates. According to a review study, infected people who remain asymptomatic play a significant role in the ongoing pandemic, but their relative number and effect still remain uncertain ${ }^{(18)}$.

Some characteristics of COVID-19 make it difficult to manage and confront the disease. In general, the incubation period, time between exposure to the virus or infection and the onset of symptoms of COVID-19, is on average 5 to 6 days, and can reach up to 14 days ${ }^{(19)}$. The most common symptoms are fever ( $\geq$ $\left.37.8^{\circ} \mathrm{C}\right)$, cough, dyspnea, myalgia and fatigue, which are widely reported in our study, with the majority presenting more than one of these symptoms, although commonly mild. Furthermore, the accuracy of the laboratory methods depends on the method used, time of illness and viral load, which makes the final diagnosis more complicated $^{(20)}$.

We were also struck by the fact that the data were collected during the period of the pandemic when the COVID-19 case curve in Brazil was on the rise and, as a result, there were a high number of new cases and deaths. However, the data revealed a scenario of continued sexual practices (casual, drug-using, unprotected, group sex) by MSM at levels similar to those recorded in studies slightly prior to the pandemic ${ }^{(21-23)}$, suggesting that this scenario may have worsened in subsequent months.

The high ${ }^{(24-25)}$ number of partners, especially those who manifested signs and symptoms, caused amazement. Engaging in sex with a casual partner in times of coronavirus implies having contact with someone with an unknown history of exposure and outside their "place of isolation" (26). If this meeting was held with more than one partner and involved drug use, the adoption of SARS-CoV-2 prevention measures may have been even more hindered ${ }^{(24,26)}$. This finding is corroborated by the statistical association between the presence of signs and symptoms and quantitative partners

The increase in levels of anxiety and stress caused by the rupture of socio-affective networks is intensified by apparent phenomena such as the lack of social interaction, entertainment, leisure, or loneliness and boredom. These factors have a great influence on the behavior of the MSM population ${ }^{(27-28)}$ during the pandemic context and should also be taken into consideration. Associated, they can constitute complicating agents for the prevention and control of the disease, since the political actions in health aimed at this population are considerably weak in much of the global scenario(29).

It is relevant to mention that this is a study carried out in a Latin American country that has been facing several obstacles in the advancement of public policies directed at the LGBTQIA+ population ${ }^{(24,26,30-31)}$. This scenario, which is permeated by LGBTQIA+ institutionalized phobia, may compromise health protection, since, in the absence of proper and safe apparatuses, MSM may be resorting to resources and practices that expose them to SARS-CoV-2.

In addition, there were no institutional health educational actions in Brazil that would produce alternatives, strategies and/ or measures aimed at sexual practices and behaviors of MSM in order to support them in addressing the impacts generated by the pandemic within this dimension of human life. Thus, the need for the development of governmental actions focused on harm reduction is emphasized, considering that, for various reasons, the results revealed that MSM are maintaining the practice of casual sex during the presence of the epidemic course of $\mathrm{CO}$ VID-19 in Brazil.

\section{Study limitations}

In addition to the caveats already presented, this research has a number of limitations that must be pointed out. First, the study was conducted only online, with self-reported information, and it 
is not possible to check their veracity. Secondly, the method of data collection makes it difficult to establish causal relationships, because it is not known for sure if the signs and symptoms began after or before casual sex. Although this may be pointed out as a limitation, simple contact with another person in the presence or recurrence of FS signs and symptoms is relevant since presenting IS signs and symptoms before casual sex may indicate a possible partner infection, while presenting IS signs and symptoms after casual sex may indicate partner infection. Finally, we were also unable to analyze in this study the recurrence of casual sex and its implications.

\section{Contributions to Nursing and Public Health}

Based on this argumentative logic, it emphasizes the need to direct the attention of health professionals, such as those in Nursing, to the appreciation of behavioral and relational aspects, which involve the dimensions of human sexuality, together with the clinical and assistance practice in the recognition of signs and symptoms and risk factors associated with COVID-19. It should be considered that whether or not to adhere to the health measures that determine social detachment, and consequently lead to the prohibition of sexual encounters during the pandemic, is not just a question and/or logic of individual choice, but a multiplicity of factors that should be taken into consideration regarding the production of health care and Nursing, in the search to overcome stigma, blame and discrimination of sexual and gender minority groups.

\section{CONCLUSION}

Our findings show the occurrence of signs and symptoms indicative of flu-like syndrome suggestive of COVID-19 in Brazilian MSM who engaged in casual sex during the period of social isolation, with influence on the number of partners, which was proportionately higher in those who presented signs and symptoms.

\section{FUNDING}

Conselho Nacional de Pesquisa - CNPq

Process: 159908/2019-1

\section{REFERENCES}

1. Wu F, Zhao S, Yu B, Chen YM, Wang W, Song Z, et al. A new coronavirus associated with human respiratory disease in China. Nature. 2020;579(7798):265-69. doi: 10.1038/s41586-020-2008-3

2. WHO. Coronavirus Disease (COVID-19) Dashboard[Internet]. 2020 [cited 2020 Sep 03]. Available from: https://covid19.who.int/

3. Magno L, Rossi TA, Mendonça-Lima FWD, Santos CCD, Campos GB, Marques LM, et al. Challenges and proposals for scaling up COVID-19 testing and diagnosis in Brazil. Ciên Saúde Coletiva. 2020;25:3355-64. doi: 10.1590/1413-81232020259.17812020

4. Barreto ML, Barros AJD, Carvalho MS, Codeço CT, Hallal PRC, Medronho RA. What is urgent and necessary to inform policies to deal with the COVID-19 pandemic in Brazil?. Rev Bras Epidemiol. 2020;23:e200032. doi: 10.1590/1980-549720200032

5. Ministério da Saúde (BR). Covid-19: Definição de Caso e Notificação [Internet]. 2020 [cited 2020 Sep 03]. Available from: https://coronavirus. saude.gov.br/definicao-de-caso-e-notificacao

6. Mohler G, Bertozzi AL, Carter J, Short MB, Sledge D, Tita GE, et al. Impact of social distancing during COVID-19 pandemic on crime in Los Angeles and Indianapolis. J Crim Justice. 2020;68:101692. doi: 10.1016/j.jcrimjus.2020.101692

7. Bezerra ACV, Silva CEMD, Soares FRG, Silva JAMD. Fatores associados ao comportamento da população durante o isolamento social na pandemia de COVID-19. Ciên Saúde Coletiva. 2020;25:2411-21. doi:10.1590/1413-81232020256.1.10792020

8. Alpalhão M, Filipe P. The impacts of isolation measures against SARS-CoV-2: infection on sexual health. AIDS Behav. 2020;24(8):2258-9. doi: $10.1007 / \mathrm{s} 10461-020-02853-\mathrm{x}$

9. Lopes GP, Vale FBC, Vieira I, da Silva Filho AL, Abuhid C, Geber S. COVID-19 and sexuality: reinventing intimacy. Arch Sex Behav. 2020;21:1-4. doi: 10.1007/s10508-020-01796-7

10. Kline NS. Rethinking COVID-19 Vulnerability: A Call for LGTBQ+ Im/migrant Health Equity in the United States During and After a Pandemic. Health Equity. 2020;4(1):239-42. doi: 10.1089/heq.2020.0012

11. Brennan DJ, Card KG, Collict D, Jollimore J, Lachowsky NJ. How might social distancing impact gay, bisexual, queer, trans and two-spirit men in Canada? AIDS Behav. 2020;2020;30:1-3. doi:10.1089/heq.2020.0012

12. Sanchez TH, Zlotorzynska M, Rai M, Baral SD. Characterizing the Impact of COVID-19 on Men Who Have Sex with Men Across the United States in April, 2020. AIDS Behav. 2020;24(7):2024-32. doi: 10.1007/s10461-020-02894-2

13. Sousa AFL, Oliveira LB, Schneider G, Queiroz AAFL, Carvalho HEF, Araujo, TME. Et al. Casual sex among MSM during the period of social isolation in the COVID-19 pandemic: Nationwide study in Brazil and Portugal. medRxiv. 2020. doi: 10.1101/2020.06.07.20113142.

14. Eysenbach G. Improving the quality of Web surveys: the Checklist for Reporting Results of Internet E-Surveys (CHERRIES). J Med Internet Res. 2004;6(3):e34. doi: 10.2196/jmir.6.3.e34

15. Mizumoto K, Kagaya K, Zarebski A, Chowell G. Estimating the asymptomatic proportion of coronavirus disease 2019 (COVID-19) cases on board the Diamond Princess cruise ship, Yokohama, Japan, 2020. Euro Surveill. 2020;25. doi: 10.2807/1560-7917.ES.2020.25.10.2000180

16. USS Roosevelt's asymptomatic cases helping scientists understand virus. NBC 7 San Diego [Internet]. 20 April 2020[cited 2020 Sep 03]. Available from: www.nbcsandiego.com/videos/uss-roosevelts-asymptomatic-cases-could-help-scientists-understand-virus/2309131 
17. Felsensteina S, Hedrich CM. COVID-19 in children and young people. Lancet Rheumatol. 2020. [In Press]. doi: 10.1016/ S2665-9913(20)30212-5

18. Oran DP, Topol EJ. Prevalence of Asymptomatic SARS-CoV-2 Infection: A Narrative Review. Ann Intern Med. 2020;3:1-7. doi:10.7326/M20-3012

19. Ministério da saúde (BR). Diretrizes para diagnóstico e tratamento da COVID-19 [Internet]. Brasília, 2020[cited 2020 Sep 03]. Available from: https://portalarquivos.saude.gov.br/images/pdf/2020/April/18/Diretrizes-Covid19.pdf

20. Ministério da Saúde (BR). Coronavírus [Internet]. Brasília, 2020[cited 2020 Sep 03]. Available from: https://coronavirus.saude.gov.br/ sobre-a-doenca

21. Queiroz AAFLN, Sousa AFL, Matos MCB, Araújo TME, Reis RK, Moura ME. Knowledge about HIV/AIDS and implications of establishing partnerships among Hornet ${ }^{\oplus}$ users. Rev Bras Enferm. 2018;71(4):1949-55. doi: 10.1590/0034-7167-2017-0409

22. Queiroz AAFLN, Matos MCB, Araújo TME, Reis RK, Sousa AFL. Sexually transmitted infections and factors associated with condom use in dating app users in Brazil. Acta paul Enferm. 2019;32(5):546-53. doi: 10.1590/1982-0194201900076

23. Sousa AFL, Queiroz AAFLN, Fronteira I, Lapão L, Mendes IAC, Brignol S. HIV Testing among middle-aged and older men who have sex with men (MSM): a blind spot? Am J Mens Health. 2019;13(4):1557988319863542. doi: 10.1177/1557988319863542

24. Rocha GM, Guimarães MDC, Brito AM, Dourado I, Veras MA, Magno L, et al. High Rates of Unprotected Receptive Anal Intercourse and Their Correlates Among Young and Older MSM in Brazil. AIDS Behav. 2020;24(3):938-50. doi: 10.1007/s10461-019-02459-y

25. Alecrim DJD, Ceccato MGB, Dourado I, Kerr L, Brito AM, Guimarães MDC. Factors associated with exchanging sex for money in men who have sex with men in Brazil. Ciênc Saúde Coletiva. 2020;25(3):1025-39 doi: 10.1590/1413-81232020253.18052018

26. Sousa AFL, Queiroz AAFLN, Lima SV, Almeida PD, Oliveira LB, Chone JS, et al. Prática de chemsex entre homens que fazem sexo com homens (HSH) durante período de isolamento social por Covid-19. Cad Saúde Pública[Internet]. 2020[cited 2020 Sep 03]; In Press.

27. Aquino EML, Silveira IH, Pescarini JM, Aquino R, Souza-Filho JA, Rocha AS. Medidas de distanciamento social no controle da pandemia de COVID-19: potenciais impactos e desafios no Brasil. Ciênc Saúde Coletiva. 2020;25(Supl.1):2423-46. doi: 10.1590/1413-81232020256.1.10502020

28. Sousa AR. How can COVID-19 pandemic affect men's health? a sociohistoric analysis. Rev Pre Infec e Saúde. 2020;6:10549. doi: 10.26694/ repis.v6i0.10549

29. Silva BSM, Inês D, Denise AL, Vivas MJG, Kerr LRFS. Social networks of men who have sex with men: a study of recruitment chains using Respondent Driven Sampling in Salvador, Bahia State, Brazil. Cad Saúde Pública. 2015;31(Suppl-1):170-81. doi: 10.1590/0102-311X00085614

30. Bowleg L. We're not all in this together: on COVID-19, intersectionality, and structural inequality. Am J Public Health. 2020;110(7):917. doi: 10.2105/AJPH.2020.305766

31. Salerno JP, Williams ND, Gattamorta KA. LGBTQ populations: psychologically vulnerable communities in the COVID-19 pandemic. Psychol Trauma. 2020;12(S1):S239-S242. doi: 10.1037/tra0000837 